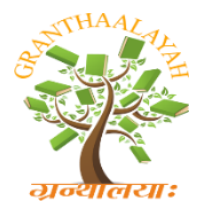

INTERNATIONAL JOURNAL OF RESEARCH GRANTHAALAYAH A knowledge Repository

Social

\title{
INDIAN DIASPORA AND TRANSLATION STUDIES IN MAURITIUS
}

\author{
Shrestha Pandey ${ }^{* 1}$ \\ ${ }^{* 1}$ Research Scholar, Lucknow University, Lucknow, India
}

\begin{abstract}
The present paper aims to study the functions of literary translation and Indian diaspora writers with special reference to Mauritius, a small island being multicultural, multiethnic and multilingual. Our study includes the presentation of the situation of literary translation in Mauritius and analysis of some of the major works translated to query challenges of post-colonial translation. The corpus includes two translations chosen where Mauritian Creole is now part of the target language (eg Boy, transcreation of Misyon garsonby Lindsey Collen). The translation into Creole an, in fact, literalization of language and to establish a literary heritage. The translation is rewriting in our two Mauritian authors, which in the case of the rewriting of The Tempest in Creole, Dev Virahsawmy makes speech-cons when choosing this time to rewrite the Creole English and Lindsey Collen, aims to make available the novel-reader Mauritius. The handwriting in Lindsey Collen also helps address the problem of translation of spoken language (Creole) in a written language.
\end{abstract}

Keywords: Translation; Mauritius; Diaspora.

Cite This Article: Shrestha Pandey. (2019). "INDIAN DIASPORA AND TRANSLATION STUDIES IN MAURITIUS." International Journal of Research - Granthaalayah, 7(12), 110-114. https://doi.org/10.5281/zenodo.3595321.

\section{Introduction}

It is interesting to note how translation turns into rewriting in the works of the two Mauritian writers, rewriting where The tempest is a literary means to write back to the Empire for Dev Virahsawmy while Lindsey Collen finds a way in rewriting her to Broaden Novel non-Mauritian to readers. Rewriting in the case of Lindsey Collen's Boy also sheds light on the problem of translating from an oral to a written language.

The critical post-colonial claims as one of its fields to study the literary translation, the focal point would be in their common interest contacts of cultures and languages. In their study comparing the post-colonial writing and literary translation, Maria Tymoczko wrote that the understanding of literary post-colonial could benefit from the body of knowledge that has built in translation. But go in both directions. 
As stressed by Susan Bassnett and Harish Trivedi it is common to see the emergence in the former colonies of concepts challenging western norms of practice the translation. It is the empire's response that it seems interesting to study the function of literary translation in a post-colonial including Mauritius, a beautiful example of a multicultural and multilingual society. The presentation of the Indian diaspora in Mauritius and analysis of two works translated examine the issues of translation in post-colonial period.

Devoid of indigenous people but in turn colonized by Dutchman (1598-1710), the French (17151810) and British (1810-1968), this small island Indian Ocean, Mauritius, is a rich multicultural society - through the mixing of people from Europe (settlers), Africa (slaves) and Asia (the Indian indentured labores and Chinese traders) - multilingual and complex which combines English (language administrative official), French (language of gentrification), Creole (language tongue of over $90 \%$ of the population but long discredited and relegated to status of "dialect") and some Asian languages like Hindi, Tamil, Hakka etc. This would explain a literary production uneven in many Languages of Mauritius, the choice of writing language-dependent status it enjoys in both nationally and internationally. Indeed, as some languages are considered "major / mainstream". Thus, literature written in Mauritius mostly in Hindi, French, English and French language production is "undoubtedly the most old - it has more than two centuries of existence - and richest". It also has English voices which mostly date to the sixties as Suchilla Gopaul and if the writings of Ramesh Bucktawar, Shakuntala Hawldar, Ramkarrun Jokhoo and especially Lindsey Collen have been added to the literary heritage, their number and visibility remain below the influence of French publications.

The French, Hindu and English (three major languages) are, therefore, preferred by Mauritian authors and widely read by all Mauritian school (teaching in the Mauritian educational system is in both English and French), translation literature is not widespread in Mauritius.

It is not a lack of interest but rather a non-need felt by the Mauritian intellectuals. Thus, translation literary present along these lines in Mauritius. We have:

- translation from French and English in other European languages Mauritian authors best known nationally and internationally. Some Examples of these translations are from French into English (and Around Varanasi of Babylon Barlen Pyamootoo), from French to Spanish (and Pagli Sigh Ananda Devi) from English into French (Getting rid of it and "There is a tide of Lindsey Collen's poems Hawaldar Shakuntala), from English to German (There is a tide and The Rape of Sita by Lindsey Collen) and English in Turkish (Mutiny by Lindsey Collen). These authors, mostly, are published in publishing French (Gallimard, L'Olivier, Dapper) and British (Bloomsbury) and therefore have a higher profile than those published locally;

- translations of classical French and English Creole: Moliere (The Tartuffe The Imaginary Invalid etc..) Beaumrchais (The Barber of Seville) and Shakespeare (Macbeth, The Tempest, Romeo and Juliet, Much Ado About Nothing, Julius Caesar, Hamlet, Othello, The Merchant of Venice) for example;

- translations of French Creole and English. An example is part of Dev Virahsawmy Li Translated in both languages respectively Carpanin Marimoutou and Rameh Ramdoyal. We also have self-translations Creole French: When mountain comes dife/ blight Renee Asgarally, Creole and English: Misyon Garson / Boy by Lindsey Collen; 
- translation of Hindi into English and French. The French translation of story of Abhimanyu Lal Pasina Unnuth for example, is published under the title Sweating blood in Editions Stock.

- and some translations from French into Hindi, including that of Paul and Virginia by Basdeo Bissoondoyal. We note that except for cases (a) where the translation occurs between languages Europe more or less equal, the three other cases are translated into one or a minor language such as Creole and Hindi. Indeed, the translation may be a important issue in terms of dedication and visibility for literature written in minor languages like those produced by a minority in a language major (by definition of "minor literature" given by Deluuze and Guattari "Translation is the large body of specific consecration of the library universe. Unrecognized as such because of its apparent neutrality, it is yet the way main access to the literary world for all writers 'quirky' is a form of literary recognition".

Thus, Lindsey Collen translated Misyon Garson making it accessible to more wider audience (other than Mauritius) what she had written in an act activist promoting Creole years ago. Hence the many changes made to the original text. Indeed, Lindsey Collen reorganizes the narrative architecture removing the first chapter and the division into chapters of the Creole version. She adds details, informative "cornflakes (and) tea/cereals (and) tea (10) for synecdoche "said/tea (1) which refers to breakfast in the context Mauritius, or the physical portrait of the mother Garson as a reader - is the Mauritian not imagine not necessarily as a very traditional Hindu Protecting visa-vis its offspring. Thus, the passage telling how Garson feels smothered by its mother is reflected in a lengthy description of the missing version Creole when it comes to its water-to-dress, gaudy colors of the shawl and noise her bracelets invading the space of the young man. Another example where Lindsey Collen explicit what is obvious to the reader of Mauritius, where is the mother of Garson practicing a religion where you do not eat beef or pork, forbidden his son to eat sausages for fear of sin.

As for Toufann, translation-adaptation of the play The Tempest canon, it is faces away from the source text but to the Mauritian public. Indeed, Dev Vihahsawmy takes the frame of the story but allows some freedoms when it invests Mauritian concerns and is recited in color and intonation delicious Creole that are also accessible to an audience of Mauritius. A example is the transformation of the names of Shakespearean characters: Stephano (the drunk) and Trinculo (the jester) in Dammarro and Kaspalto. These stereotypes Mauritian referring to smoking cannabis and traitor. Dev Virahsawmy plays on the double meaning of "kaspalto, particularly in Act III Scene I where the master summoned Kaspalto, character-traitor who turn his coat easily, and Prospero, heard "kaspalto" think the captain asked him to remove his jacket. If Dev Virahsawmy promoted the works of one culture to another and enhances the heritage of literature called "ex-centric" by embezzlement literature, it seeks especially dedicate this minor literature as well as the minor language.

Toufann chooses to celebrate miscegenation born of the encounter between different cultures during colonization. The Metis Kalibann (Caliban in The Tempest) is presented in the stage directions of Toufann not as savage and misshapen monster described by Shakespeare but a handsome man about 25 years old, intelligent and resourceful. Its man is the new world which is also made king by marrying Kordelia who bears his child, as mestizos. The child here is contrary to the desired threat uttered by Caliban to impose its progeny in Miranda. At Prospero protesting 
in front the lack of blue blood Kalibann, Kordelia says she is satisfied that the blood human flows in his veins. The inclusion of English proverbs and cliches and the presence overcorrection of the French highlight the problem of linguistic imperialism spreading among former colonial perversion belief in the superiority of those who mastered the language of the colonizer. Accordingly, Roshni Mooneeram33 The cons-speech in Toufann lies in the fact of making exotic English language by inserting a few words English translation in Creole function normally attributed to the inclusion of Creole in literary texts from English or French from former colonies. To linguistic imperialism (monolingual), Dev Virahsawmy response by cross-breeding language as shown in choosing the tile of his play. "Toufann" is a term Bhojpuri (a dialect spoken by the Ancient Indian indentured laborers to Mauritius) to mean "storm" while the Creole translation would "Cyclone" (tropical storm which falls annually on the island during the months of December to February). Such a choice can only underline the dynamism of Creole, which is permeable the different languages (French, English, Hindi, Hakka etc..) with which it is contact.

Lindsey Collen seems to suggest as a solution what Michael calls 'self-translation (re) creative "because only the author can claim the right to modify, add and delete leeway that the translator would hardly dare acquire. Michael defines self-translation (re) creative based on this Hugh Kenner suggest that from the practical self-translating from Samuel Beckett. Translation of postcolonials attempts to say the same in the language of the other leads as we have seen a reappropriation of the original text to make rewriting. It will thus enabled our two post-colonial writers of thedefamiliarization dominant language (English) during a meeting with a dominated language (Creole) as the poet wrote the Caribbean, Edouard Glissant : "I speak in you language and it in my language that I understand" Major Mauritian writers of Indian diaspora whom I shall discuss in the thesis are Anand Mulloo, Ramesh Bucktawar, Ramkarrun Jokhoo, Deep Chand Biharry, Sadasinh Dhanveer, Ananda Devi, Sewtohul, Ramsurrun, Vijay Naraidoo, Shakuntala Hawoldar, Chintamanee Chummun, Sairta Budhoo, Satcam Boollel, and others for the study and analysis of Indian diaspora in Mauritian Writing in English and Dev Verahsawmy and Lindsey Collen for translation works.

\section{References}

[1] Bassnett, Susan \& Trivedi, Harish (ed.), Post-colonial Translation: Theory and Practice, London / New York : Routledge, 1999.

[2] Bernabe, Jean, Chamoiseau, Patrick \& Confiant, Raphaël, Èloge de la Crèolitè, Paris : Gallimard, 1993.

[3] Bessiere, Jean \& Moura, Jean-Marc (èd.), Litteratures postcolonial et francophonie : conferences du seminaire de litterature comparèe de l Universilè de laSorbonne Nouvelle, Paris : Honorè Champion, 2001.

[4] Casanova, Pascale, La Repubique mondiale des Lettres, Paris : Seuil, 1999.

[5] Collen, Lindsey, Boy, London: Bloomsbury, 2004.

[6] Collen, Lindsey, Misyon Garson, Grande Riviere (Maurice) : Ledikasyon Pu Travayer, 1996.

[7] Deleuze, Gilles \& Guattari, Fèlix, Kafka. Pour une littèrature mineure, Paris : Èdutions de Minuit, 1975. Francofonia No. 48. La litterature mauricienne de langue francaise, Firenze (Italie) : Olschki Editore, printemps 2005.

[8] Lionnet, Francoise, «Creole Vernacular Theatre : Transcolonial Translations in Mauritius » in Revi kiltir Kreol No. 3, Port Louis (Maurice) : Nelson Mandela Centre for African Culture, octobre 2003, pp.1-12. 
[9] Mooneeram, Roshni, Creative Writing in Mauritian Creole: The Emergence of a Literary Language and its Contribution to Standardisation, These soutenue à ;'Universitè de Leeds, 2001.

[10] Nirsimloo-Gayan, Sooryakanti ; Tranquille, Danielle (éd.), Rencontres. Translation Studies, Moka (Maurice): Mahatma Gandhi Institute Press, 2000. Notre Librairie No. 114. Littérature mauricienne, Paris: Clef, juillet-septembre 1993.

[11] Oustinoff, Michaël, Bilinguisme d'écriture et auto-traduction. Julien Green, Samul Beckett, Vladimir Nabokov, Paris: L'Harmattan, 2001.

[12] Tranquille, Danielle, Toufann: une fantaisie en trois actes, Port Louis (Maurice) : Educational Production Limited, 2004.

[13] ................................ « Translator: Trans Alter. A reflection on Dev Virahsawmy's Toufann » in Revi kiltir Kreol No. 3, Port Louis (Maurice): Nelson Mandela Centre for African Culture, fevrier 2003, pp. 34-45. Triplopia volume IV issue 2, spring 2005.

[14] Virahsawmy, Dev, Foufann : enn fantezi entrwa ak. Rose Hill (amurice): Boukiè Bananè, 1991.

[15] Voisset, Georges \& Gontard, Marc (sous dir. de), Ècritures corbìbes, Rennes: Presses Universitaries de Rennes, 2002.

\footnotetext{
*Corresponding author.

E-mail address: onupadhyay21@yahoo.com
} 